Family stories, public silence: Irish identity construction amongst the secondgeneration Irish in England

Bronwen Walter, Department of Geography, Anglia Polytechnic University, Sarah Morgan, Irish Studies Centre, University of North London, Mary J. Hickman, Irish Studies Centre, University of North London and Joseph $\mathbf{M}$. Bradley, Department of Sports Studies, University of Stirling 


\section{Family stories, public silence: Irish identity construction amongst the second- generation Irish in England}

Formal narratives of history are central to the construction of national identities (Johnson 1992). But diasporic communities are cut off from the representation of an important strand of their histories by a series of absences from spaces of cultural reproduction, in education, memorials and popular culture more widely. The population who experience this disjuncture most sharply are the 'second generation', those whose parents were born and raised in a different culture. At least some aspects of this culture are passed on in the intimate space of child rearing, but at school age most markedly, second-generation children are thrust into a public sphere where this culture is underrepresented or may be missing altogether.

For colonised populations this may entail a more active suppression of dissident identities in order to avoid contestation and speed up the process of incorporation into the national mainstream. Mary J. Hickman (1996) shows that Irish history has been conspicuously excluded from the curriculum in Britain since the nineteenth century, not only of state schools, but also from the separate Catholic school system, where the majority of children of Irish descent are educated. She argues that this has been a key element in the denationalization of the Irish in Britain and their construction as good Catholic British citizens. The need to control threatening Irishness by redefining it as religious difference is a distinctive feature of this particular 'diaspora space’ (Brah 1996). As Marella Buckley points out: 
Another difference between Irish ethnicity in Britain and that in other countries is the assimilationist approach in Britain towards all expressions of Irishness, whether immigrant or nor (Buckley 1997:112).

However knowledge of their cultural background in Ireland cannot be erased. It continues to be handed on to British-born children both intentionally and unconsciously. This paper explores some of the ways in which Irish histories are passed to the second generation, enabling them to acquire a different perspective on the national story being told in the diaspora space in which they live. Because the national stories of Britain and Ireland continue to clash, this de-centred knowledge has an ongoing political significance for people of Irish descent in Britain. One of the key purposes of the introduction of the Prevention of Terrorism Act in 1974, for example, was to dissuade British residents from expressing views sympathetic to the Irish nationalist population in Northern Ireland and questioning the state's political and military strategies there. Since 'the propaganda war' ensured that strict censorship was being practised in the public sphere, access to alternative constructions was confined to private - family or community - sources (Cathcart 1984, Curtis 1984, Miller 1994).

The Irish constitute a major element in the diaspora space of Britain, which Brah (1996) defines very inclusively as

A conceptual category [which] is 'inhabited', not only by those who have migrated and their descendants, but equally by those who are constructed and represented as indigenous. In other words the concept of diaspora 
space (as opposed to that of diaspora) includes the entanglement, the intertwining of genealogies of dispersion with those of 'staying put'. The diaspora space is the site where the native is as much a diasporian as the diasporian is the native (Brah 1996:209)

Because the Irish have settled in Britain on a large scale since the early nineteenth century, their genealogies are deeply intertwined with those of the English, Scottish and Welsh. Not only are social relations complexly interwoven in the public sphere, but at a personal level rates of intermarriage have been high (Walter 1984) and indeed appear to be increasing quite rapidly. In 1971 over 40\% of second-generation Irish people had two Irish-born parents, whereas in 1991 the proportion had fallen to 23\% (Hickman, Walter and Morgan 2001). This is often taken to be evidence of assimilation, of a loss of a distinctive ethnic identity. However an alternative theorisation is that of hybridity, in which both placed and displaced identities are held in tension, their expression varying contextually in time and space (Rattansi 2000). The notion of hybridity allows for conceptualisation of new forms of identities which arise out of experiences of 'dwelling-in-displacement' Clifford 1994). For Lavie and Swedenborg (1997) these are represented by the hyphen itself in hyphenated identities, space constituted from, but not reducible to, either of the national/ethnic entities which surround it. In the case of the Irish in Britain, of course, the assumption of assimilation is reinforced by a lack of a hyphenated name to give public recognition to this hybridity.

But people of Irish descent continue to remember their different family pasts. In particular contexts these hybrid constructions may emerge in strongly oppositional 
ways. Mark Boyle (2002) identifies a situation in the urban West of Scotland where he claims that

\begin{abstract}
Across the past decade there has been a qualitatively important development in the currency of particularly virulent and potent memories of Ireland's past, among at least some sections of the Irish Catholic community (2002:174).
\end{abstract}

He is referring to the 'rebel music scene' in Strathclyde where young men gather in backstreet venues where bands perform the hero-martyr genre of songs, with, for him, a frighteningly violent edge. Boyle argues that this is a displaced politics of identity, related more to the experiences of job losses and shifting gender relations than to actual involvement in the politics of Ireland today. Rather than an expression of 'living memory’ (milieu de memoire) in Pierre Nora’s terms, he sees this is an example of 'lieux de memoire' ('merely’ sites of memory) which characteristically ‘flare up’ as ‘memories are beseiged, conquered, tyrranised and eradicated by history’ (Nora 1989:13).

Context, both spatial and temporal, is therefore crucial to an understanding of different ways in which the nation is narrated in the Irish diaspora. The West of Scotland is a very specific location where ethnic difference and the persistence of Irish identity has been labelled sectarianism, notably through the media and its reporting of the sports contest encountered by Celtic and Glasgow Rangers football teams (Bradley 1995, 1996). The relevance of Irish and religious identity in the westcentral belt of Scotland is far removed from the day-to-day experiences of people of 
Irish descent amongst different sections of the Irish population and in other parts of Britain.

Within the diaspora space of England, sectarianism is confined to a few pockets, for example parts of Liverpool and parts of the north. Remaining antagonisms between Catholicism and Protestantism in the rest of England take a much more muted form, but the experience of 'growing up Catholic' still sets children apart from the national Protestant norm. Meg Maguire, who grew up in London, describes the particular spatial and temporal context of this way of life:

My experiences of growing up as a working-class girl/woman of Irish Catholic descent are rooted in a specific historical moment and a particular locale - south London. Growing up and being schooled in the 1950s and 1960s in a deeply devout Catholic Irish family has a uniqueness and a specificity which have yet to be recognised and which are as yet undocumented (Maguire 1997:89).

This paper examines a different site, where narratives of the Irish nation are produced and reproduced amongst second-generation Irish people living in a small English Midlands town with predominantly English neighbours. It forms part of a wider research study, the Irish 2 Project, exploring the identities and experiences of people born in Britain to one or two Irish-born parents. Five geographical locations in Britain - London, Glasgow, Manchester, Coventry and Banbury - were selected in order to construct a sample including people with a wide range of regional and local backgrounds. Here we focus attention on the smallest centre, Banbury in Oxfordshire 
(population 45,000 in 2000), and explore the public/private duality of Irish identity experienced by people who have spent at least part of their lives in this very 'English' context.

Irish migrants have settled in England on a large scale at least since the early nineteenth century. Although certain centres have attracted significant clusters particularly London, the North-west region of England and in the post-Second world War period, the West Midlands - there has also been a wide spread across all counties (Walter 1980). In large part this has reflected subsequent migration following the continuous redistribution of job opportunities. Those living in large centres can choose to be more securely ensconced within an Irish 'world', with provision of community meeting places, regular cultural activities, schools where the majority of people share a similar heritage and work networks.

In smaller centres, by contrast, Irish people are more isolated, interacting with the majority population in all spheres of life. The experiences of this sample are the most varied in the research study, including people born and raised in much larger Irish communities, who have subsequently migrated, and those who have lived only in a variety of smaller ones, including Banbury itself. Without specifically-labelled Irish meeting places many people may be unaware of the presence of other Irish people in the town and have no reason to meet them. The majority English population will also lack signposts to the existence of an Irish presence, except through personal friendships and casual acquaintance, thus rendering the Irish an 'invisible' population in the town. 


\section{Methods}

Discussion groups were chosen as an exploratory tool. Since the aim was to examine the possibility, and dimensions, of Irish-British identities, this shared and interactive method was chosen as the first stage of data collection. A process of construction may take place within a group of people whose identities are invisible in the majority society, and who have no formal opportunities to reflect on their situation.

People with one or two Irish-born parents were invited to take part in the groups. We advertised extensively for participants - in local newspapers, radio programmes, Irishorientated media, libraries, Irish community workers and centres, doctors’ surgeries, newsagents’ windows and by snowballing. In Banbury a particularly important contribution to recruitment was an article printed in the local weekly newspaper the Banbury Guardian by a journalist who caught the spirit of the research very perceptively (30 November 2000). The headline ‘Do you feel you are Irish?’ opened up the issue of second-generation identities in a provocative and intriguing way. It was reproduced as a half-page spread on the front page in the free newspaper the Banbury Citizen next day under the title 'How Irish do you think you are?', which again succeeded in catching the eyes of a wide variety of people of Irish descent in the town (1 December 2000).

The article included a description of the study's aims, stressing that a wide range of feelings might be experienced, followed by two brief interviews with local people whose parents were born in Ireland. Each was a young man with an Irish surname, but they expressed sharply divergent views. These reflect formal and informal 
understandings of ethnic identity, the first speaker formulating ethnicity as nationality, whilst the second refers to a more emotional, undefinable sense of ethnic identity.

...Banbury United footballer, Kieran Sullivan, has always considered himself English and will not identify himself as Irish in the 2001 census.

Mr Sullivan, 32, of Burns Road, said: 'I sometimes feel Irish when it comes to sport but not in everyday life. I think nationality breaks down to your place of birth and where you spend your time.

I sound English and I don't know if my name has any bearing with people when they meet me'.

Van driver Eddie Quinn was born in this country but says that he feels Irish because of the way he has been raised.

Mr Quinn, 27, has been to Ireland many times to see his family and learned Irish dancing as a boy.

He attended Blessed George Napier School where many children have Irish parents and thinks his experiences have made him aware of his heritage. He said: 'Yes, I think I am Irish. I don’t know why because when it wasn’t taught to me but when I was younger I was always going to Ireland'.

Responding to a request at the end of the article for volunteers, about thirty people came forward to participate in the research. Clearly an interest in their Irish heritage prompted their participation. This was a necessary part of their willingness to participate and to give time to mulling over in depth with others their feelings and personal experiences. But they had very varied backgrounds - a wide range of class 
positions, a mix of local-born and in-migrant backgrounds, a broad age range and an even gender balance. Particularly interesting was the inclusion of several people with Protestant backgrounds from both Northern Ireland and the Irish Republic. These were very hard to recruit in the other interview locations, but had no difficulty in seeing a place for themselves in the research study outlined in the Banbury Guardian and perhaps in expressing this difference in a small-town context. The article's pitch also brought responses from several 'low identifiers', a category vital to the success of the project but very time-consuming to locate in the other research sites.

From these volunteers discussion group members were chosen to provide a demographic and social mix approximating to that of the known statistical profile of the second-generation Irish in Britain (Hickman, Morgan and Walter 2001). Discussions lasting approximately two hours were held with two groups of 3-4 members. These were later followed by in-depth semi-structured interviews with twenty individual participants, including group members, which developed the issues raised. Prior to the interview each person completed a three-generation 'Family Tree' providing demographic data and information about parents', siblings' and children's identification, education, employment and health. These Family Trees also helped to flesh out family relationships and dynamics as their intricacies unfolded during discussion.

The sample included thirteen people who had two Irish-born parents, three who had an Irish-born mother only and three with an Irish-born father. One non-Irish-born parent was of Irish descent, but the others were stated to be English without any known Irish connection. The remaining interviewee had an Irish birth mother but had 
been adopted by an English couple. They were Catholic and his adoptive mother had distant Irish ancestry. He had not yet made contact with his birth mother, but an interest in his Irish origins prompted him to take part in the project.

\section{The local context: Banbury}

Banbury is located on the edge of the South East region of England, between Oxford and Coventry. The local tourist guide describes it as lying in the 'heart of middle England'.

Picturesque rolling landscapes are dotted with the distinctive market towns of Banbury to the North and Bicester and Kidlington Village to the South, each with their own charm and hidden delights (Cherwell District Council, undated)

Before 1915 the majority of in-migrants were from the local area, with an increasing proportion from southern England in the period up to 1935. Only 4/292 of the representative sample of immigrants arriving before 1935, interviewed in 1950 for Margaret Stacey’s first Banbury study, were from Ireland (Stacey 1960). The town remained a small local centre until 1960s when it was formally designated an expanding town. 'Overspill' agreements with both London and Birmingham rapidly pushed its population from 19,000 in 1951 to 25,000 in 1966. In 1966 the large food manufacturer Birds (now Kraft Suchard after a series of multi-national takeovers), moved from Birmingham and brought many employees, including Irish workers (Stacey M., Batstone E., Bell C. and Murcott A. 1975). At this time large public 
housing estates were built in the town, including a new Catholic church (St Joseph the Worker, 1968) and school to meet the needs of the newly-arrived Irish population. The longstanding presence of English Catholics in the town is attested by the imposing landmark of St John’s church (1828) in the town centre.

However the numbers of Irish people remained a very small proportion of the total. Respondents laughed when we asked them whether Banbury could be regarded as an 'Irish’ town in any way. The only connection they drew was with the Catholic churches where they knew or assumed that the congregations included many people of Irish descent. But there was no specifically Irish provision in the town, though at times in the past there had been Irish dancing classes. The only named Irish activity was the Banbury Irish football team where young men were mainly recruited from the Catholic comprehensive school, Blessed George Napier. St Patrick’s day was not celebrated in any communal way. Very few could identify an 'Irish’ pub.

In some cases parents had moved directly from Ireland to Banbury, following a family or friendship network. Thus three participants in the project had been born and bred in Banbury and only one of these, perhaps significantly a Protestant woman, described herself as a 'Banbarian'. More commonly an initial move by parents from Ireland to England was to a larger centre such as London (five) and Birmingham (three), followed by later relocation to Banbury to find work and housing. Four participants had arrived in Banbury as children and attended schools there. But for more than half, arrival in Banbury had been part of a more complex set of moves in adulthood involving many locations in southern England. Work, housing and sometimes marriage, were the main factors drawing them to the town. There was thus 
considerable variation in people’s experiences of living in more and less strongly 'Irish’ contexts over the lifecycle.

\section{Public accounts of Irish history in Britain}

Respondents were asked about their knowledge of, and interest in Irish history. For most people the study of national histories is primarily connected with compulsory elements of formal education, possibly supplemented in adulthood with voluntary activities including courses, reading and other popular media forms. However the most striking aspect of the Banbury participants' encounters with Irish history outside the home was its absence from the school curriculum. Even in Catholic schools history lessons were about British history and they could not remember Ireland being mentioned. Unusually one person used an option in her A-level Sociology course to make a video about Northern Ireland. This absence has been analysed closely by Mary J. Hickman in her study of the experiences of London and Liverpool children of Irish descent (Hickman 1990, 1993).

In the Banbury sample it was women in particular who described themselves as 'ignorant', a term often tinged with guilt and regret, or as ‘a bit interested in Irish history but not very knowledgeable'. Men did not admit this as a lack, but described ways in which they had increased their knowledge. The realisation that this has been a missing part of their cultural knowledge has come to the respondents later in their lives. All the respondents who grew up with an Irish-born parent were to varying degrees interested in filling in some of the gaps. Many now describe themselves as self-taught. Often an impetus is to gain an understanding of the Northern Irish 
Troubles, which they feel in particular has been missing from the British culture in which they grew up. The desire to know more about the issue is also fuelled by British people's expectation that those of Irish descent will be better informed, and so able to supply information, regardless of what part of Ireland their parents originated from.

People used a variety of formal and informal methods to gain an understanding of Irish history as adults. Participation in taught courses on Irish topics was rare. Only one interviewee, a woman who trained at a Catholic teacher training college, had enrolled in an Irish history option. Another respondent had been awarded a place at Ruskin College, Oxford through his trade union activity. He chose the topic of James Connolly, the second-generation Irish trade unionist and Irish nationalist for his dissertation topic. However one man in his fifties had recently enrolled in an Irish language class in London.

Larger number reported searching for Irish history books in the public library or finding websites. But without guidance they sometimes found it difficult to know where to start.

Q. Are you interested in Irish history, do you read about Irish history?

Louise (born Cambridge, 1956, both parents Irish): I would love to read about Irish history if I could find a book that put it to me in simple English, some of them are so complicated. I have stood in Banbury Library thinking I can't read that, I'd love to read it, but I can't do that. 
Peter has been in book shops for the last five years looking for a decent book on Irish history, I think I have got him interested. I made him read Angela's Ashes. I would like to know more.

Most respondents made a point of watching documentaries and dramas about Ireland when they were shown on television, as well as going to see films such as Michael Collins. Louise made immediate connections with her own family:

I went to see the Michael Collins film a few years ago when it came out. I know it wasn't absolutely accurate, and I remember walking out of the cinema and saying to Peter, to everybody else: 'They have just watched a film, I have watched part of my family history’.

The initiation in adulthood of a search for knowledge about their Irish heritage illustrates the fluidity of hybrid identities. The widely accepted theory of rapid Irish assimilation in Britain, suggesting a linear trajectory over time, is called into question by evidence of an increasingly confident assertion of difference. Interviewees felt able to belong to several 'pasts' simultaneously as they lived the experience of dwellingin-displacement.

\section{Family stories: private accounts of Irish history}

Family homes are the places where Irish issues can be most safely discussed (Walter 2001). As Buckley observes: 
The domestic threshold of immigrants can also mark a boundary of difference inside which identity and cultural practices which refer to the country of origin may be maintained and shielded from the alien environment of the street (Buckley 1997:110-111).

However the knowledge that second-generation Irish people had acquired about Irish history within the family was in most cases fragmentary. There was very little evidence that parents had consciously passed on to their British-born children any of the strongly nationalist formal history curriculum to which they were undoubtedly exposed themselves in the 1930s and 1940s (Johnson 1992). But even where there was little factual knowledge of wider historical events imparted, children grew up with a strong sense of an alternative story in their family's past.

In some cases this was openly discussed. In interviews people reported hearing stories about British atrocities in the War of Independence of 1920-22.

Marie (born London, 1951, Irish mother, English father): Mum remembers an old lady where she lived having all her possessions thrown out in the street, because her sons were members of the IRA, that sort of thing. That is as we were older we heard about things like that.

Louise (born Cambridge, 1956, both parents Irish): Yes, she told some very strange stories. Looking back one of my uncles was involved in an incident 
where the English went to the football match and fired guns into the crowd. The IRA then went to sort out the English in a hotel and shot the English in their beds. One of my uncles was supposedly involved in that incident. She would tell you the story. In the same way other children might have been told the story of Cinderella we'd get stories of IRA activity. In her mind, her anti-Englishness was with her before she came to England.

Tara (born Dover,1967, both parents Irish): My parents would often mention political history going back even further than that. My dad would get really incensed if anybody went on about how marvellous Winston Churchill was. I'm not entirely certain of the political details, but he was no friend of the Irish. And go back even further to Oliver Cromwell. He was really dragging them up. And how Oliver Cromwell had massacred all these hundreds of Irish.

But others experienced silence at home and only picked up more indirectly on the sense of an oppositional history.

Q: Did your parents talk to you about Irish history?

Paul (born Leigh, Lancs, 1942. Irish father, English mother): No, not even my father.

Q: He was interested but didn't talk to you about it?

Paul: I don't think he was interested in Irish history as history, but he was interested in the feeling of Irish nationalism. I have upstairs, and when I 
was filling the form out, I took out the family documents. Amongst them was one of the first things I remember associating with my father. The cigarettes he smoked then used to have flags of the world on a bit of silk. I still have with me Irish Free State, and that's the one my father kept and I ended up with. It is valued and it is an emotional thing.

Some parents made a deliberate decision to put things behind them, especially those with painful personal connections. One man contrasted his own curiosity as a child with the silence of his parents.

Q. Would you say you were interested in Irish history?

Brian (born in London, 1952, both parents Irish): Because of the Troubles, that is what has triggered me to find out why is there turbulence in that country. To find out. My parents had never spoke about it. I had not known about any Irish history.

Q: Why hadn't they talked about it, was it the sort of thing they didn't talk about, or they weren't terribly interested?

Brian: They must have been interested as it must have affected them. My parents are very quiet people, it was a mystery to me, why is this going on in the British Isle, I wanted to find out.

Q: $\quad$ So it wasn't something you'd grown up knowing, hearing conversations that might have explained it to you, it just wasn't talked about? 
Brian: There was nothing before the 1970s no real news, but it must have always been there.

Q: $\quad$ So your parents weren't saying things to you about previous British attitudes to Ireland which may have been the cause of the Troubles?

Brian: No nothing.

Q: $\quad$ You taught yourself?

Brian: Found out yes, I bought books in the book store.

Q: Did you talk to other people about what you were reading, or just by yourself, take it in and think about it?

Brian: May be to other Irish people to get their views, pull information from them. I remember my father was born in 1920, when I asked him he said 'The Black and Tans came and burned the haystack and killed the cow', and that was all he'd say.

Q: $\quad$ So you then spoke to your parents, but didn't find out any more?

Brian: No.

This respondent had not accepted his parents' attempts to bury the past and sought other avenues to learn about Irish history. But he still utilised 'safe' methods of discussing and learning about Irish history - reading and buying books as a private activity and talking to ‘other Irish people’. 
An older man had experienced much closer and more traumatic links with violent historical events in his own childhood. His English wife initially contacted the project on her husband's behalf because she knew he would like to participate but had strongly conflicting feelings about his family's Irish past. His parents had been caught up in the Irish Civil War of 1922-23 and became political refugees. His father was a member of the Royal Irish Constabulary and had been forced to leave by IRA. The family had fled to England with the support of unknown Northern Irish sponsors living in Britain who offered to vouch for them.

Dan (born Lincoln, 1931): When they left Mayo, they had to move as somebody burnt their house down. They went to Dublin to Dublin Castle, and he was still a Policeman there, and when they were disbanded he came to England, and she came a little later.

Q: $\quad$ You heard a lot of these stories as a child did you?

Dan: No, they would rarely talk about the past.

Q: $\quad$ They were upset about it?

Dan: Not upset, like a lot of things you draw a line and get on with the rest of your life. They did the same. There was none of this wanting to go back or mix with Irish people, they were good mixers and happy to be here. 
This respondent had been sent back to live in Irish-speaking Mayo in the 1930s, between the ages of two and six, because the family in England could not support ten children whilst the father remade his career. He did not return to Ireland until the mid1990s because the deep ambivalence he felt between his deep attachment to Ireland as a small child and his parents' rejection of the country because they had been forced to leave.

Memories of British rule in Ireland continued beyond the declaration of independence for people whose parents were brought up in Northern Ireland:

Grace (born in Letchworth, 1946, both parents Irish): So when I was little they were talking about before the current thirty-year Troubles started, I was brought up to think that the British in Ireland were a bad thing. Then there were the B Specials, how anti-Catholic they were, and we heard lots of tales about people being stopped. Lots of stories about how impossible it was for a Catholic to get a good job in Ireland. You only had to answer the question of which school did you go to, and they would know. You then had no chance of promotion in the civil service or any career prospects at all. So that is what I remember as a child, and then I was going to college when the main trouble started.

The intersections of family memories with Irish histories also included more local, social accounts of past events. Women reported these stories more frequently than men. 
Q: When you were growing up did your parents talk about family history?

Rachel (born in Banbury, 1972, both parents Irish): Yes, all of the time.

Q: It was always being talked about and you just listened and asked questions?

Rachel: Yes, and tell us that story again .

Catherine (born York, 1952, Irish mother, Scottish father): My mother has always told stories about what mammy did, not that she can remember much of that. We have pored over the family albums. We have lots of good photos of the Ballygally days. My mum was brought up partly in Ballygally and partly in Belfast. So yes, and even more so now my father has been writing his memoirs, and I keep saying to my mother you should write yours. She said she hasn't got time, she has too much cooking to do. I don't know for whom. But I wish she would sit down and write them down, there is a whole rich social memoir there. Particularly of the war years, she talks a lot about that.

Some children, however, were actively discouraged from asking questions. Grace explained that family history was not discussed in her household. It was considered rude for children to ask adults questions about their background. A reluctance to talk about the family's past in Ireland was also related to family 'secrets'. Another woman described such a situation: 
Louise (born Cambridge, 1956): I remember driving to a funeral we were going from Dublin to Sligo for a funeral, one of my cousins was driving a car, and my mother's sister was in the front seat. We were going through Phoenix Park, and my cousin pointed out the window at a house and said 'That should have been ours, that was family money, that should have been ours'. My aunt just told us to be quiet, she was nearly fifty years of age. She said 'Be quiet I am concentrating on my driving. We can't discuss this now'. I knew what it was about, but it was one of those family secrets. Colette was trying to tell me about the house, which we were passing, but it was frowned upon. I don't know how much of that was not telling us because it was going back to England, or not telling us because it wasn't discussed. I am sure the family history, if you tried to unravel secrets, it would be tremendous.

Most second-generation children thus augmented their fragmentary knowledge when they met their Irish relatives face-to-face on holidays to Ireland. These were important occasions for a reintegration of families split by emigration and a chance to hear stories at first hand from relatives who had remained. However there was a clear bimodal division between families who kept close physical contact with Ireland and those who rarely visited. Amongst the latter considerable regret was expressed by respondents that they had been deprived of close family connections.

The accounts given by the Banbury sample illustrate the wide variation in family knowledge about the national past of their Irish-born parents and grandparents. These relate to the placing of the family within the context of political events as well as to customs, attitudes and continuing contacts. Having only one Irish-born parent did not appear to dilute the strength of the historical narrative being absorbed, indeed it may 
have heightened its distinctiveness. Gender differences in both the givers and receivers of accounts have also been identified. This supports Nira Yuval-Davis's (1997:1) argument that 'constructions of nationhood usually involve specific notions of both "manhood" and "womanhood”. But exploration of this is 'only a very recent and partial endeavour' so that much remains to be theorised (Yuval-Davis 1997:3). For both women and men, however, the national story being painted, however faintly, for children in households that were to some extent 'Irish' was fascinatingly different from that being absorbed from the English culture around them.

This difference was brought out clearly by the respondent with an Irish birth-mother, who was brought up by adoptive ‘English’ parents. He dissociated himself entirely from the Northern Irish conflict:

Dick (raised in Mansfield, Nottinghamshire, born 1951): I think some of the things the Irish spout are idiotic, that is because I think our way of looking at it is probably better. I have no time for the troubles, they are a waste of time, people. And to call yourself Northern Irish is an anachronism because you are not Irish really. Scots, a lot of them.

Dick had no hesitation is aligning himself with the British ('our way') in opposition to ‘the Irish'. However he also said he might mention his Irish 'roots' in Irish company, and had a slight interest in Irish history.

Dick: I am on the periphery of wanting to learn about what caused the troubles, the potato famines and why they all went across to America. I 
won't spend time doing it. However on the other hand I am an ardent supporter of my children learning about British history.

Although he did not express feelings of dislocation, Dick's situation illustrates Paul Garrett's concern that Irish children, especially those adopted by English Catholics in the 1950s and 1960s, may lose their Irish cultural and national heritage. He argues that Social Services Departments are still unaware of Irish children's heritage and need to 'evolve a more culturally appropriate response to the placement needs of Irish children’ (2000:23). The situation may be rather different for children adopted at birth rather than in later stages of childhood, which raises the issue of the biological inheritance of ethnic identities, perhaps particularly salient in societies such as Britain where ethnicity is understood in racial terms.

\section{Cultural background: unacknowledged difference}

Despite the absence of an ethnic category, or indeed a named hyphenated identity, knowledge of a different national past on at least one parent's side persists amongst the second-generation Irish. Thus 'Irish identities remain highly significant for a diverse range of Irish people in Britain' (Hickman 2000). But the distinctiveness of an Irish cultural background is not recognised in Britain at a popular level. Participants in the discussion groups reflected on the differences between themselves and other second-generation populations. They compared themselves to 'white' European populations, like the Italians, whose cultural background remained 'audible' in traces of accent and dialect. 
Tara (born Dover, 1967, both parents Irish): I think it's important that people understand that being second-generation Irish/British, it can be quite difficult. From my experience I never quite know what I am doing, who I am, where my loyalties lie. When you are brought up with a particular culture, in this case an Irish culture, which obviously all of us here have in our lives. You are living in Britain and you have English friends, it's quite difficult to get across you have almost got a dual life. That must be the experience of Asians in Britain, and it is no different. To have Irish now included as an ethnic minority, I think that is right. We might look the same as your average English person, on the whole, but it is a different experience. I think that needs to be put across really.

James (born London, 1961, both parents Irish): That is very, very true. I talk to the lad that works next to me, who is second generation Indian, Sikh. I was talking to him, and he was saying yes, there are elements of the culture which are still quite strong, because he is living in the Sikh community.

Q: Born over here?

James: Yes, born over here, but still talks slightly differently. Then that was true of lads I went to school with from Italian background. They were born and brought up here, they were in my school, but they talked very differently to the way that I spoke. They almost spoke with an Italian accent, because at home they all spoke Italian. That is another thing of course, being Irish, 
I don't know whether others do, but we didn't speak Irish at home, and my parents didn't speak Irish.

People of Irish descent are themselves unused to asserting this cultural difference. The 2001 Census ‘Ethnic Question’ was a two-stage procedure. People were asked ‘What is your ethnic group? Choose one section from (a) to (e) [White, Mixed, Asian or Asian British, Black or Black British, Chinese or Other ethnic group] then tick the appropriate box to indicate your cultural background'. Many of the Banbury respondents, who explained in focus group discussions that they felt strongly Irish because of their childhood experiences of growing up in Irish families, nevertheless initially ticked 'British' in the belief that this was an official 'fact'. They had no previous experience of being offered 'cultural background' as a significant part of their identity, and overlooked or misunderstood it when it appeared on the Census form. After the group discussions, several decided that 'Irish' described their sense of ethnic identity more closely, though the majority would have preferred a 'mixed' category of ‘ $50: 50$ ’ British and Irish. This confusion over formal and informal levels of ethnicity mirrors and illuminates the apparently divergent views expressed by the two young men interviewed by the Banbury Guardian journalist (see above).

James: It also says indicate your cultural background. Largely my cultural background is Irish. If that's what you are brought up with, what is in the house, and what your interests are, then it is.

Q: You would then tick Irish because you saw cultural background?

James: Yes, because it says cultural background. If it says are you British or are you Irish, I am British, I wouldn't question that. 
Q: Did everyone else pick up on the cultural background?

Tara: No

Brian: No, not at first, but I did tick British, even with the cultural background.

Tara: Cultural background I would tick Irish, but I wouldn't necessarily have noticed that.

As the above exchange illustrates, the discussion groups of the Irish 2 Project itself provided an unusual space for second-generation Irish people to explore their senses of cultural difference. This group expressed their pleasure in having the opportunity to discuss issues of second-generation identity and experience with others from similar backgrounds. None of them knew each other before the meeting but they discovered many common strands in their lives which had not previously found a more public forum.

James: It is recognition though, that is the main thing. I have found this tonight to be really interesting. The only other opportunity I get is if I am talking to cousins, who like me were born here. Then when you sit down and start talking to them about it, they understand, they know what you are talking about. When you say about the duality of am I this, am I that, I am but I am not.

\section{Conclusion}


Diaspora spaces include by definition peoples with different cultural backgrounds. For those whose difference is marked by visibility, for example skin colour or clothing, or by audibility, including language or accent, these cultural differences are acknowledged by the majority. They may be indeed be overdetermined in the case of assumptions made on the basis of skin colour. Min and Kim (2000) describe the painful but gradual establishment of an ethnic identity amongst second-generation Asian-American professionals who had managed to hide their ethnic culture and 'nonwhite' characteristics during their early school years but were not allowed to do so in college. But for 'white' groups raised and educated in Britain, whose language patterns have become almost indistinguishable from the 'white' majority, such cultural difference is unrecognised. 'Whiteness' signifies sameness with the ‘indigenous’ mainstream.

Yet within the diaspora space of England a significant 'white' minority population has not shared the political and historical understandings of the English-origin majority. These oppositional views have been contained by the exclusion of knowledge in the public sphere and its encapsulation within the private domestic sphere. Such memories cannot be erased altogether. They re-emerge through the connections people make about the relationship between their individual, family and national identities.

Second-generation Irish people in Banbury took as their starting point family stories, closer to the oral history tradition of Nora's 'milieux de memoire', which he describes as 'unselfconscious, commanding, all powerful, spontaneously actualising' (Nora 1989:7). However they also felt a need to place these stories within a wider 
national picture so that 'lieux de memoire' in the form of secondary academic and media historical accounts were being actively sought in their adult lives. Although several expressed interest in pursuing family history through genealogy, it was the broader political context which attracted them most. In contrast to the young male population of the West of Scotland who expressed their frustration collectively in rebel music, however, this group of 'Irish-English’ people strengthened their sense of a shared national heritage by an individual search process.

The sharpened awareness of their national past highlights the 'unfinished business' of de-colonisation of Ireland, both in traumatic memories of the violent accomplishment of Independence in 1920-22 and in the re-ignition of the Troubles in Northern Ireland after 1968. Mary Lennon, Marie McAdam and Joanne O’Brien reviewed the lifestories of Irish-born women in Britain in Across the Water (1988):

One woman we interviewed said, 'History is the beginning and the end of the Irish person,' and we certainly identified with this way of looking at it. A sense of our own history is very strong amongst Irish people in a way which people in Britain often find mystifying. Most women we talked to felt this. The need to locate ourselves historically also appears to be reinforced by living over here and confronting that lack of information which so many British people have about Ireland and also, about their own history. Against this background many Irish people living in England feel that they can’t afford not to know something about their own history. (1988:13) 
Those who are born and raised in Britain inevitably encounter elements, if very muted, of 'an imperial mentality’ which has 'penetrated everyday life, popular culture and consciousness' (Runnymede Trust 2000). The authors of the Parekh Report argue that this too remains an unresolved issue.

It remains active in projected fantasies and fears about difference, and in racialised stereotypes of otherness... There has been no working through of this collective imperial experience (2000: 24-5).

Perhaps the clearest indication of this is in the different historical memories retained within families. What distinguished all but one of the respondents from their English neighbours in Banbury was an empathetic response to those suffering in the Northern Ireland 'troubles' and a willingness to educate themselves about the underlying causes of the violent incidents presented in the media. They had access to different sources of historical memory which challenged the censorship and propaganda which produced a hegemonic belief in Britain that the 'problem' was the inability of two religious tribes to live peacefully together, which necessitated the peacekeeping input from even-handed, justice-loving Britain.

All interviewees in Banbury regarded IRA bombers as 'extremists' whom they could not support. But with one exception they drew a clear line between them and the vast majority of 'ordinary people’ in Northern Ireland whom, unlike most English people, they did not blame for the situation. They were thus very far from being the 'suspect community' against whom the Prevention of Terrorism Act was introduced in 1974. Yet they belonged to a population group which was routinely subjected to harassment 
and unnecessary delay at air and seaports when they made family visits to Ireland (Hillyard 1994, Hickman and Walter 1997).

Second-generation Irish people in Britain have hybrid identities which draw on two contrasting and at times conflicting cultural traditions. Such hybrid identities claimed by children of migrants are not simply mixtures of pre- and post-migration cultures, providing some measurable indication of 'progress' from one to the other, but new entities constructed out of the experience of 'dwelling-in-displacement' (Clifford 1994). The contribution of these two traditions varies in different geographical locations in Britain. In Banbury people of Irish descent found few opportunities to express the Irish elements in their hybrid identities. But family memories persisted within the domestic sphere and in many cases strengthened over time as people reflected on their senses of identity in adulthood. These findings challenge notions of assimilation amongst the children of Irish migrants in Britain and point to the need for more nuanced understandings of 'white' diasporic identities.

\section{Acknowledgements}

This research was funded by Research Grant R000238367 from the Economic and Social Research Council. We would like to thank Guy Beiner and two anonymous referees for their helpful comments.

\section{References}

Banbury Citizen (2000) ‘How Irish do you think you are?’ 1 December 
Banbury Guardian (2000) 'Do you think you are Irish?’ 30 November

Boyle, M. (2002) 'Edifying the rebellious Gael: uses of memories of Ireland’s troubled past among the west of Scotland's Irish Catholic diaspora' in D. Harvey, R. Jones, N. McInroy and C. Milligan , Celtic Geographies: old cultures, new times London: Routledge.

Bradley, J. (1995) Ethnic and religious identity in modern Scotland: culture, politics and football, Aldershot: Avebury.

Bradley, J M. (1996) 'Facets of the Irish Diaspora', Irish Journal of Sociology 2 6: 79100 ,

Brah, A. (1996) Cartographies of diaspora: contesting identities, London: Routledge

Buckley, M. (1997) "Sitting on your politics: the Irish among the British and the women among the Irish” in J. McLaughlin (ed) Location and Dislocation in Contemporary Irish Society, Cork : Cork University Press pp.94-132.

Cathcart R. (1984) The most contrary region: the BBC in Northern Ireland 19241984, Belfast: Blackstaff Press

Cherwell District Council (undated) North Oxfordshire: the Cherwell Valley Banbury: Cherwell District Council 
Clifford, J. (1994) 'Diasporas’, Cultural Anthropology 9:302-338.

Garrett P. M. (2000) ‘Responding to Irish ‘invisibility’: anti-discriminatory social work practice and the placement of Irish children in Britain', Adoption and Fostering 24.1:23-33

Hickman, M. (1990) 'A study of the incorporation of the Irish in Britain with special reference to Catholic state education: involving a comparison of the attitudes of pupils and teachers in selected secondary schools in London and Liverpool', unpublished Ph.D.thesis, University of London Institute of Education, London.

Hickman, M. (1993) 'Integration or segregation? The education of the Irish in Britain in Roman Catholic voluntary-aided schools', British Journal of Sociology of Education 14.3:285-301.

Hickman, M.(1995) Religion, class and identity: the state, the Catholic Church and the education of the Irish in Britain, London: Avebury.

Hickman M. (1996) ' Incorporating and denationalizing the Irish in England: the role of the Catholic church' in P. O’Sullivan (ed) The Irish Worldwide Volume5 Religion and identity, Leicester: University of Leicester Press pp. 196-216

Hickman, M. and Walter, B. (1997) Discrimination and the Irish community in Britain, London: Commission for Racial Equality. 
Hickman M., Morgan S. and Walter B. (2001) The second-generation Irish: a demographic, socio-economic and health profile, London : University of North London

Hillyard P. (1993) Suspect community: people's experience of the prevention of Terrorism Acts in Britain, London: Pluto Press

Min P.G. and Kim R. (2000) 'Formation of ethnic and racial identities: narratives by young Asian-American professionals', Ethnic and Racial Studies 23.4:735-760

Johnson, N. (1992) 'Nation-building, language and education: the geography of teacher recruitment in Ireland, 1925-55’, Political Geography 11:170-189.

Lavie, S. and Swedenburg, T. (eds) 1996) Displacement, diaspora and geographies of identity, Durham,SC: Duke university Press.

Lennon M., McAdam M. and O’Brien J. (1988) Across the water: Irish women's lives in Britain, London: Virago

Maguire, M. (1997) 'Missing links: working-class women of Irish descent', in P. Mahony and C.Zmroczek (eds), Class matters: ‘working-class' women’s perspectives on social class, London: Taylor and Francis. 
Miller, D. (1994) Don't Mention the War: Northern Ireland, propaganda and the media, London: Pluto Press.

Nora P. (1989) 'Between memory and history: les lieux de memoire', Representations 26: 7-25

Rattansi A. (2000) ‘On being and not being brown/black’ Interventions, 2.1:118-133

Runnymede Trust (2000) The future of multi-ethnic Britain. The Parekh Report, London: Profile Books

Stacey M. (1960) Tradition and change: a study of Banbury, Oxford: Oxford University Press

Stacey M., Batstone E., Bell C. and Murcott A (1975) Power, persistence and change: a second study of Banbury, London: Routledge and Kegan Paul

Walter B. (1980) 'Time-space patterns of second wave Irish settlement in British towns’, Transactions Institute of British Geographers, New Series 5:297-317.

Walter B. (1984) 'Tradition and ethnic interaction: second wave Irish settlement in Luton and Bolton', in C Clarke, D Ley, C Peach (eds.)Geography and ethnic pluralism, London: George Allen and Unwin. 
Walter B. (2001) Outsiders inside: whiteness, place and Irish women, London:

Routledge

Yuval-Davis N. (1997) Gender and Nation, London: Sage 